\title{
Biomass Production of Poplar Plantation Ecosystem in Yangtze River Beach Land
}

\author{
Jianfeng ZHANG ${ }^{1}$, Qixiang SUN ${ }^{2, *}$, Jinxing ZHOU ${ }^{2}$, Qihua SHAN ${ }^{1}$, Lixun WU \\ ${ }^{1}$ Institute of Subtropical Forestry, Chinese Academy of Forestry, Fuyang, China \\ ${ }^{2}$ Institute of Forestry, CAF, Silvicultural Laboratory of SFA, Beijing, China \\ ${ }^{3}$ Forestry Academy of Hunan, Changsha, China \\ *Author for corresponding, Email: sunqixiang@263.net
}

\begin{abstract}
Currently, China is home to more than four million hectares of oil plants nationwide, and 154 kinds of energy trees could produce seeds containing more than 40 percent of oil, with total production of the seeds totaling five million tons. Another 57 million hectares of waste land are available and suitable for planting trees for the production of forest-based bioenergy, of which there is $630,000 \mathrm{hm}^{2}$ beach land in the middle and lower reaches of Yangtze River where is suited for poplar growing. In order to approach the potential of poplar biomass production, the test was conducted in the paper. The result indicated that in the poplar forest ecosystem the herbaceous biomass production was $15.554 \mathrm{t} / \mathrm{hm}^{2}$. While biomass production for trees was $43.164 \mathrm{t} / \mathrm{hm}^{2}$, totally in the poplar plantation ecosystem biomass production reached $58.718 \mathrm{t} / \mathrm{hm}^{2}$. As well, poplars growing added incomes for local farmers.
\end{abstract}

Keywords: biomass production, poplar plantation, Yangtze River

\section{Introduction}

Based on abundant information from the National Bureau of Statistics and listed companies, in 2007, China's fuel ethanol output reached 1.6 million tons, of which $80 \%$ used corn as raw materials. Based on the proportion 1:3.3, more than four million tons of corn was consumed. It is estimated that China's annual fuel ethanol output will reach five million tons in 2010 and utilization rate of ethanol gasoline will be more than 50\%. Moreover, cornbased ethanol has stopped expanding production capacity, as government policies have clearly restricted the development of grain-based ethanol. Therefore, developing non-grain ethanol has become an inevitable trend [1]. It is forecasted that China's biodiesel output will reach two million tons in 2010.

China's biological energy power generation has developed rapidly and the total installed capacity has reached 2.2 million $\mathrm{kW}$, of which 1.7 million $\mathrm{KW}$ was from $\mathrm{Ba}-$ gasse co-generation and 500,000 $\mathrm{KW}$ was powered by agriculture and forestry wastes, methane, direct-burning of rubbish and landfill gas. Generally speaking, efforts made to develop biological energy are still limited, therefore, China's bioenergy has a huge potential for future development.

China has sufficient raw materials resources for pro-

The research is funded by State Tenth Five-year Plan of Science \& Technology Project (2006BAD03A15) duction of biomass. Only the agricultural wastes can be converted into energy, which is equivalent to 500 million tons of standard coal and 350 million tons of crude oil (about 2.5 billion barrels).

There is $630,000 \mathrm{hm}^{2}$ beach land in the middle and lower reaches of Yangtze River, including island-type beach, the continent beach, the lake beach, etc. three kind of types. This is the extremely important natural resource in view of much more population and faster urban expansion there [2]. But because natural vicissitude, mainly the human factor disturbance, the beach land ecosystem is received the enormous destruction, cannot display the ecological function, the economic benefits and the social efficiency which it should have.

On the other hand, planting poplar tree in the beach, not only fully uses the natural resource, increases the incomes for local people, moreover the poplar tree also has the function of biomass production. Therefore, the development of poplar forest in the beach could improve the local ecological environment along the middle and lower reaches of Yangtze River, and promote regional socioeconomic processing as well [3].

\section{Experimental Location and Methods}

\subsection{Experimental Location and Natural Conditions}

Experimental location lied at Dongting lake region in Yueyang, Hunan Province, among the north latitude 
$29^{\circ} 31^{\prime} 40^{\prime \prime}$ and east longitude $112^{\circ} 51^{\prime} 34^{\prime \prime}$. It is of the subtropics moist monsoon climate characteristic, much rainfall in the summer, while in the autumn much drought, in the winter \& spring severely cold. Annually mean precipitation $1200.7 \sim 1414.6 \mathrm{~mm}$, yearly average relative humidity $80 \%$. The annual mean temperature $16.5 \sim 17.0{ }^{\circ} \mathrm{C}$, accumulative temperature over $10{ }^{\circ} \mathrm{C}$ is $5254.1 \sim 5529.2$ ${ }^{\circ} \mathrm{C}$, extreme lowest temperature $-13.7{ }^{\circ} \mathrm{C}$, extreme highest temperature $39.3{ }^{\circ} \mathrm{C}$. Frost-free period $263.7 \sim 276.6 \mathrm{~d}$, yearly sunshine time $1644.3 \sim 1813.8 \mathrm{~h}$ [4].

The observation point is located at Junshan district, the terrain is smooth, and its elevation equally is $31 \mathrm{~m}$. The soil layer fertility is higher, the vegetation is luxuriant. Dongting Lake's flood season appears usually in JuneAugust. The flooding time yearly is $20 \sim 50 \mathrm{~d}$, the longest may reach $130 \mathrm{~d}$.

Poplar species mainly belong to Euro-American ones, the clones include: poplar 2KEN8 $(P$. deltoides ' $2 \mathrm{KEN} 8$ '), poplar 55/65 (P. deltoides ' 55/65 '), poplar NL-80121 $\left(P .{ }^{\prime}\right.$ nanlin $\left.80121 '\right)$ and so on. Experimental stands were planted in 2000 , the density is $495 / \mathrm{hm}^{2}$, spacing is $4 \mathrm{~m} \times 5 \mathrm{~m}$, average DBH approximately $14 \mathrm{~cm}$, average tree height approximately $16 \mathrm{~m}$. Under the forest the herb coverage is $70-80 \%$, the main species include: Cynodon dactylon, Oenanthe Javanica, Ranunculus sieboldii, Leonurus Artemisia, Rumex Japonicus, Carex spp, Paederia scandens, Cirsium Japonicum, Erigeron annuus, Achyranthes aspera, Triarrhena Iutariori Paria and so on.

\subsection{Research Methods}

The research on biomass production of poplar plantation ecosystem is through measuring firstly the biomass of trees including above- and underground parts according to the method of standard stand inventory, then for herb's biomass production is the alike.

\section{Results and Analysis}

\subsection{Biomass Production of Poplar Trees}

The measurement was done at 5-year poplar stand performed separately in December 2005 and November 2006. Firstly stand sample was chosen, then conducted inventory. According standard stock was selected. The indicators were shown at Table 1.

Table 1. Survey of poplar stocks

\begin{tabular}{ccccc}
\hline $\begin{array}{c}\text { Measure } \\
\text { date }\end{array}$ & $\begin{array}{c}\text { DBH } \\
(\mathbf{c m})\end{array}$ & $\begin{array}{c}\text { Height } \\
\mathbf{( m )}\end{array}$ & $\begin{array}{c}\text { Stem } \\
\text { height } \\
\mathbf{( m )}\end{array}$ & $\begin{array}{c}\text { Mean crown } \\
\left.\text { area } \mathbf{( m}^{\mathbf{2}}\right)\end{array}$ \\
\hline $\begin{array}{c}\text { December } \\
2005\end{array}$ & 16.54 & 13.58 & 4.28 & 4.63 \\
$\begin{array}{c}\text { November } \\
2006\end{array}$ & 17.54 & 14.87 & 4.22 & 4.67 \\
\hline
\end{tabular}

Table 2. Dry biomass of poplar tree unit: $g$

\begin{tabular}{cc}
\hline items & Biomass(dry weight) \\
\hline Stem & 45578.87 \\
Branches & 16395.17 \\
Leaves & 1307.13 \\
Bark & 8275.78 \\
Roots & 13487.21 \\
Litter & 2155.44 \\
Total & 87199.61 \\
\hline
\end{tabular}

Table 3. Investigation of herbs in poplar stands in June

\begin{tabular}{cc}
\hline Species & Mean height $(\mathbf{m})$ \\
\hline Oenanthe javanica & 62 \\
Artemisia iavandulaefolia & 56 \\
Alternanthera philoxeroides & 31 \\
Carex spp. & 35 \\
Ranunculus sieboldii & 27 \\
Leonurus artemisia & 48 \\
Clinopodium gracile & 24.7 \\
Polygonum Iapathifolium & 18 \\
Rumex japonicus & 43.5 \\
Poa Faberi rendle & 10 \\
Clinopodium chinense & 27 \\
Achyranthes aspera & 42.5 \\
Cirsium japonicum & 108.57 \\
Erigeron annuus & 14.6 \\
Hemistepta iyratae & 60 \\
Clinopodium repens & 50 \\
Hemarthria altissima & 5 \\
Paederia scandens & 51.67 \\
Triarrhena Iutarioriparia & 75 \\
Galium aparine var. tenerum & 10 \\
Cynodon dactylon & 42.5 \\
\hline
\end{tabular}

In order to study the stock biomass production, different parts such as stem, root, branch, leaf were collected and measured. For underground one, survey area was 4 $m \times 5 m$, i.e. nutrition area of the tree, roots were graded into several classes such as $<\mathrm{lcm} 、 1-5 \mathrm{~cm} 、 5-10 \mathrm{~cm}$ 、 $>10 \mathrm{~cm}$ according to root diameter. The results were given out in Table 2.

From Table 2 it was shown that the dry biomass of the average single standard stock was $87199.61 \mathrm{~g}$. The density of the stand is $495 / \mathrm{hm}^{2}$, therefore in this ecosystem biomass production of poplar trees is $43.16 \mathrm{t} / \mathrm{hm}^{2}$. 
Table 4. Investigation of herbs in poplar stands in October

\begin{tabular}{cc}
\hline Species & Mean height $\mathbf{( m )}$ \\
\hline Leonurus artemisia & 20 \\
Polygonumi apathifolium & 19 \\
Alternanthera sessilis & 10 \\
Oenanthe decimhens & 6 \\
Viola betonicifolia & 8 \\
Achyranthes aspera. & 18 \\
Carex spp. & 20 \\
Cnidium monnieri & 2 \\
Rumex japonicus & 4 \\
Cynodon dactflon & 16 \\
Hemarthria altissima & 7 \\
Ranunculus sieboldii & 3 \\
Phragmites australis & 40 \\
Paederia scandens & 4 \\
Calystgia sepium & 4 \\
\hline
\end{tabular}

\subsection{Biomass Production of Herbs}

For herbs and litters biomass production the research method is the alike with trees. The survey was carried out in June and October, 2006. Since in June it was in flooding season, in October not, so that vegetation species and life stage were various. The survey results were shown as Table 3 and Table 4.

It indicated that the plant community in different season is varied from Table 3 and Table 4. Accordingly biomass production of herbs and litters should be the sum of the two inventories.

In the Yangtze River flood season, the understory herb growing in spring and summer all submerges submarine [5]. After the water draws back, the forest land basically did not have the vegetation growing. Hence the vegetation investigated after October all was newborn biomass. Therefore the biomass of herbs should be sums of the two investigations.

In June the herbaceous biomass investigation demonstrated that the understory herb biomass was $10.11 \mathrm{t} / \mathrm{hm}^{2}$, the underground root system biomass occupies always about $40 \%$ of the aboveground one, i.e. $4.044 \mathrm{t} / \mathrm{hm}^{2}$. Hence in June the herbaceous biomass production amounted to $14.154 \mathrm{t} / \mathrm{hm}^{2}$.

In October the herbaceous growth situation sees Table 4. Compared with Table 3, it is discovered that the amount of species reduced; moreover the average height obviously was lower than before. Through 12 samples which area covers $1 \mathrm{~m} \times 1 \mathrm{~m}$ investigation, the herbaceous biomass demonstrated that the understory herb biomass was $1.00 \mathrm{t} / \mathrm{hm}^{2}$. As discussed above, the underground root system biomass was $0.40 \mathrm{t} / \mathrm{hm}^{2}$. In October the herbaceous biomass production amounted to $1.40 \mathrm{t} / \mathrm{hm}^{2}$.

Generally spoken, in the poplar forest ecosystem the herbaceous biomass production is $15.55 \mathrm{t} / \mathrm{hm}^{2}$. While biomass production for trees is $43.16 \mathrm{t} / \mathrm{hm}^{2}$, totally in the poplar plantation ecosystem biomass production reached $58.72 \mathrm{t} / \mathrm{hm}^{2}$, of which trees accounting for $73.51 \%$ of the total, and herbs taking $26.49 \%$.

\section{Conclusions and Discussions}

China has been anxious to boost its use of alternative energy in recent years as its heavy reliance on burning coal to meet energy needs has caused serious environmental problems. The government plans to reduce the percentage of coal in consumption to 66.1 percent by 2010 from 69.1 percent in 2005, while improve renewable energy usage, excluding hydropower, to 0.4 percent from 0.1 percent.

The country plans to produce more than six million tons of forest-based biodiesel and will increase the installed capacity of renewable, biomass-based power generation by more than 15 million kilowatts by 2020 . The potential of the country's forest-based bioenergy would thus be equivalent to 200 million tons of coal, the utilization of which would reduce the consumption of fossil energy by 10 percent. Ultimately, biomass can be used in carbon-negative energy systems, and reduce carbon dioxide emissions even further.

In this research, through above mentioned measurement and analysis, it was shown that in the 5-year poplar forest ecosystem biomass production reached 58.72 $\mathrm{t} / \mathrm{hm}^{2}$, of which trees accounted for $73.51 \%$ of the total, and herbs took $26.49 \%$. This fact indicates that the beach poplar forest has the very big biomass production and carbon sequestration function.

According to the State Forestry Administration, China will establish 13.33 million hectares of forests by 2020 to produce liquid and solid biofuels for power generation and transport. The hectarage will rise from a planned 833,33 hectares in 2010 and provide enough biomass to produce over 6 million tonnes of biodiesel a year and power generators with capacity of 15 gigawatts. The energy forests will contribute massively to China's already successfull attempts aimed at reducing desertification.

In view of the current situation, the research is significant.

\section{REFERENCES}

[1] J. F. Zhang, J. M. Jiang, and Q. H. Shan, "Research on the black locust (Robinia pseudoacacia) forest as biomass energy resources in Yellow River delta region," In: the Proceedings of Asia-Pacific Power and Energy Engineering Conference, 2009. 
[2] Z. H. Jiang, "Selected papers on snail control and schistosomiasis prevention through forestry ecological engineering (in Chinese)," China Forestry Publishing House, Beijing, pp. 105-164, 1995.

[3] Q. X. Sun, Z. H. Peng, and Z. M. Kang, "Research on species selection based on sites in beach land," Journal of Anhui Agricultural College (in Chinese), Vol. 25, No. 1, pp. 18-22, 1998.

[4] L. X. Wu, Z. H. Cheng, and S. F. Xu, "Research on the relation between afforestation in beach land with snail control and schistosomiasis prevention," Hunan Forestry Science and Technology (in Chinese), Vol. 23 No. 1, pp. 10-18, 1996.

[5] Y. Wang, "Research on carbon \& water flux and carbon sequestration of poplar forest ecosystem in middle and lower reaches of Yangtze River (in Chinese)," $\mathrm{Ph}$. D. Thesis, Chinese Academy of Forestry, Beijing, pp. 5-120, 2006. 